\title{
Political Biographies and Administrative Memoirs: Some Concluding Comments
}

\author{
Philip A. Selth
}

When I was invited to write this conclusion, I was asked not to give potted summaries of the earlier contributions. Rather, my task was to consider some of the major themes and issues that stand out from the collection of contributions presented for this monograph. I will do this by framing key questions for political biographers.

\section{What is 'political biography' - and does the description matter?}

The Australian and New Zealand School of Government workshop on political biographies proceeded on the basis that 'political biography' was a genre in its own right. This was reinforced by the fact that most of those attending the workshop were political scientists - or, at least, have been political science students. Geoffrey Bolton said that 'real intellectuals do not do political biography', that political biography 'is doubly suspect because it carries with it a whiff of the "great man in history" heresy', and 'is also prone to contamination with a moral agenda, or at the very least to an implication that the lives of past statesmen may convey lessons and examples to the political leaders of our own generation'. Yet, as Bolton stated, and the workshop attested, 'political biography survives'.

In her introductory essay, 'Political Biography: its contribution to political science', Tracey Arklay claimed that 'political biography is the form through which writers breathe life into archival documents such as letters, diaries, birth, death and marriage certificates, Hansard and official records to assist in the re-creation of a life'. She noted the comment by Harold Lasswell, Professor of Law and Political Science at Yale, that 'political science without biography is a form of taxidermy' (quoted in Walter 1980) or as Sir John Seeley, the nineteenth century historian, put it: 'history without political science has no fruit; political science without history has no root'. As Michael Holroyd (2003: 30) has written: 'biography began as a reinforcement of the existing order. By re-examining the past and pointing it in a new direction, it may now be used to question our understanding of the present, and affect our vision of the future'. Judith Brett (1997: 1) put it succinctly in Political Lives: 'the task of political biography is to tell the story of a political life in such a way as to make that life intelligible'.

Why should we be concerned that 'political biographical methodology on the whole [is] so ill-defined'? A good biography can 'provide students of politics 
with another perspective of how power is shared, how leaders are made not born, and how circumstances can catapult ordinary people into extraordinary situations'. Few would disagree with any of these sentiments. But are we not talking about biography as such. Is there a sub-species of 'political biography'? Does it matter? What is 'political biography'? Robert Porter (1993: 1) tells us that political biographies in Australia 'have typically been written on those who have attained leadership of their political party or of government'. There are few memoirs and biographies of the backbencher (St John 1969; Haylen 1969; Hermann 1993; Fry 2002; Duthie 1984; Gullett 1992; Kane 1989; McManus 1977). This is not surprising. It would be an unusual publisher who is interested in a book about someone few book buyers had heard about. There is also the practical problem of the record to be examined. 'A great man leaves a trail behind him - press reports, letters, official records, and a wide circle of acquaintances who also have letters and the rest, in which he is mentioned' (Pimlott 1990: 223). The emphasis at the workshop was on biographies (and biographers) of the twentieth century, and mainly Australian federal politicians; that is, on leaders of government. There have been many references to Allan Martin's two-volume biography of Menzies: A life (1993; 1999) but few to his Henry Parkes: A biography (1980). Disregarding the 79 years between the subjects' birthdates, I suggest there is no difference in subject matter that would have the latter work labelled a 'political biography' and the former not.

If Ben Pimlott's Harold Wilson (1992) and Hugh Dalton: A life (1985) are political biographies, because they were prominent in national government, is Pimlott's The Queen: A biography of Elizabeth II (1996) a political biography? Are John Toland's Adolf Hitler (1976) and Richard Bosworth's Mussolini (2004) political biographies? Andrew Roberts recently published a dual biography of Napoleon and Wellington (2002). Is this a political biography? The issue is the interaction between personality and office, between government and private passions even in people for whom governing was not their primary motivation or interest.

General Ulysses S. Grant's The Personal Memoirs of U.S. Grant (1895), one of the best written memoirs of which I am aware, is generally classified as being 'military memoirs', yet Grant was President of the United States for eight years. John Dean's biography of Warren G. Harding (2004) has recently been published in Arthur M. Schlesinger's series of books on American presidents, an interesting choice of author given Harding's reputation. There is Winston Churchill's very successful attempt to influence how he would be seen by both his contemporaries and history, The Second World War (1948-56). Few biographies bluntly state in their title that the book is a political biography, as did Jenny Hocking for Lionel Murphy: A political biography (1997). All of these biographies could be labelled as 'political biographies'. 
Trying to define a political biography is a sterile debate. ${ }^{l}$ The approach I would prefer is rather to ask which biographies, autobiographies and memoirs have influenced political institutions (including the public service) or, more commonly, which ones show how these institutions work. It is these works that have lasting value for political scientists. Jessie Street's autobiography, recently edited by Lenore Coltheart, shows how this unelected campaigner for human rights influenced both Australian and international bodies (2004). In contrast, in her recent autobiography Chika, Kerry Chikarovski, the former New South Wales minister and Leader of the Opposition, shows us little of the inner workings of government - or Opposition (2004).

\section{What is a good political biography - and what gets published?}

According to Ben Pimlott (1990: 214) 'many people with a deep interest in politics, including quite a few practitioners, look to biography for knowledge and insight. But what is on offer so frequently disappoints'. Perhaps the best example of a biography that assists us in the understanding of a political system is Robert Caro's magisterial The Years of Lyndon Johnson (Caro 1982; 1989; 2002). Three volumes down, and Johnson has still to campaign for the White House in 1960. Caro's brilliant work is not a mere biography, but more a series of superb accounts of political institutions influenced by, or having an influence on, LBJ. The first 105 pages of the most recent volume, Master of the Senate, is an account of the Senate seniority and committee system; how the Southern Senators stitched up the committee system and ran the Senate as their personal fiefdom. It could have been a volume on its own. As Caro notes on his webpage: 'to show power truly you not only have to show how it is used but also the effect on those whom it is used. You have to show the effect of power on the powerless.'

On the basis of an informal survey to establish our favourite Australian 'political biographies', Tracey Arklay pointed out that of the top five biographies (Watson 2002; La Nauze 1965; Day 1999; Brett 1992; Weller 1989), all were about a prime minister, although only two that have been selected are biographies in the traditional sense of the word. However, all of them tell us about how we are governed, explain the thinking of past leaders, and contribute to political science by illustrating how personalities affect our political structures and policy. Whatever the reason for the selection of these books - one thing is certain all have contributed to a greater understanding of how politics works. That is probably reason enough.

There is very little point in writing a biography that no one will read. They need to be published - and to be published they need to sell. As Pimlott has noted, among book-buyers, 'celebrity is the draw, quality is secondary. It is, perhaps, this market pressure that is most responsible for making the generality of political biographies valets to the famous' (Pimlott 1990: 223). It is a great pity that a 
work of such value as Geoffrey Bolton's Edmund Barton: The one man for the job (2000) would not have been published by Allen \& Unwin without the financial support of the National Council for the Centenary of Federation. Would John La Nauze's (1965) two-volume Alfred Deakin: A biography, far better as political history than it is as a biography, readily find a publisher today?

Perhaps not surprisingly, the majority of Australian political biographies and memoirs are of Labor figures. Is this because, as Pat Weller speculated, the Liberals appear to have no heroes other than Menzies? At the state level, Sir Henry Bolte, Sir Charles Court and Sir Thomas Playford might rate as heroes (Prior 1990; Blazey 1972; Crocker 1983; Cockburn 1991; Court 1995). Or is it, as Ian Hancock suggested, unlike Labor, the Liberals are not interested in the past? Is it because many Liberal politicians, when they leave parliament go into business to make money and do not have the time or inclination to pen their memoirs? This imbalance may well say something about the different approaches to life across the party divide, or something about Labor's capacity for myth-making and calamity. It is to be hoped that the gaps in our studies of Liberal and Country Party leaders at both federal and state level will soon be overcome.

What are the publishers looking for? Clearly, it is a book that will make a profit. Unfortunately, the market in Australia for a biography is small. There is not the opportunity for newspaper serialisations that in, for example, the United Kingdom, would bring in large sums for both the publisher and author. Here a political biography may get a page in the Canberra Times. But if the subject is a sporting hero, he or she may get several pages in the Sydney Morning Herald or more in the Daily Telegraph. Regrettably, the role of celebrities, gossip and hype are more likely to find a wider market than an in-depth, analytical biography of a political figure that eschews the subject's private life.

In April 2005 The Australian published a list of 'political autobiography sales' that makes interesting reading:

$\begin{array}{llr}\text { Bob Hawke } & \text { The Hawke Memoirs (hardback) } & 75,000 \\ \text { Graham Richardson } & \text { Whatever It Takes } & 45,000 \\ \text { Bill Hayden } & \text { Bill Hayden: An autobiography } & 42,383 \\ \text { Cheryl Kernot } & \text { Speaking for Myself Again } & 4,000 \\ \text { Neal Blewett } & \text { A Cabinet Diary } & 3,000 \\ \text { Kerry Chikarovski } & \text { Chika } & 295\end{array}$

Fortunately, despite the best efforts of the federal government in recent years, there is still funding for academics to conduct long term, in-depth research. The recent books by, for example, Judith Brett, David Day, Ian Hancock, Geoffrey Bolton and Pat Weller, to pick but a few, clearly benefited from the authors 
having institutional support, if only indirectly. We should also not forget the contribution that has been made to Australian scholarship by the thousands of entries in the Australian Dictionary of Biography, the editorial staff of which are housed in The Australian National University's Research School of Social Sciences. Many books and articles about Australian politics and government, and biographies, owe their origin to an entry in the $A D B$. A few owe their origin to a masters or doctoral thesis, usually extensively reworked before publication. There is also the valuable The Biographical Dictionary of the Australian Senate (Millar 2000; 2004).

John Iremonger, who died in 2002, published the works of many of our best political biographers. One of the last books Iremonger commissioned was Chris Masters' forthcoming biography of the radio personality Alan Jones. So far as I am aware, Mr Jones has never been elected to public office. Yet he very clearly meets the Australian Concise Oxford Dictionary definition of being a politician, 'a person engaged in or concerned with politics, especially as a practitioner'. It is possible that Alan Jones has more influence on New South Wales politics than anyone other than the Premier. If he raises an issue on his morning radio program critical of the government, efforts will be made to have that issue settled before lunchtime. Once Chris Masters' book has run the gauntlet of the defamation lawyers and is published, it will tell us as much about politics and government in New South Wales as the raft of books by and about New South Wales politicians that have been published in recent years (for example, Steketee and Cockburn 1986; Cumming 1991; Collins 2000; Dodkin 2003; West and Morris 2003).

Unfortunately, in Australia few diaries by politicians have been published and certainly nothing comparable to the Crossman (1975-77), Castle (1980) and Clark (1993) diaries. Only three by recent federal politicians come to mind, those by Howson (1984), Cameron (1990) and Blewett (1999). Blewett's is by far the most analytical and useful, especially for its musings on the way cabinet was run and how effective the procedures might be (Weller 2005). There is also the promise of Mark Latham's diaries, which are being published by Melbourne University Publishing in September 2005 (Latham 2005; Lagan 2005). At the state level, we know Bob Carr is keeping a diary, extracts of which are finding their way into books (Dodkin 2003). ${ }^{2}$ But, as Neal Blewett has cautioned, care needs to be taken with diaries as much as with autobiographies and authorised biographies. Blewett edited his diaries for reasons of space. Presumably no diarist deliberately washes all his or her dirty linen in public. Those extracts from unpublished diaries that are made available to others are no doubt carefully selected by their author. Blewett also made the point that politicians' diaries are usually relentlessly political, dense, unselected and turgid. Diaries are rarely kept by the most senior ministers, probably because they do not have the time to do so (Carr appeared an exception to this rule). 
Similarly, we need to exercise caution when drawing upon accounts by politicians who have a reputation to protect - and/or advance. The former Liberal politician, Peter Coleman, was recently reported as saying that political memoirs 'are usually full of lies and spin and quickly fill the remainder shelves'. Neal Blewett reminded us that Bob Hawke's massive memoir tells us little about the fall of Susan Ryan as a minister, Indonesia or the sinking of the dollar after its deregulation in December 1983. The account of how he became leader is benign. As Pat Weller noted, autobiographies are about highlights in the author's life, not routine. For John Button, personal accounts can be both informative and a pleasure to read. He tried in As It Happened (1998), very successfully, to show what it was like to be in politics, and to make the book readable. He hung his narrative around events that were of interest to him, not all of which were political.

The memoirs of prime ministers Whitlam (1985) and Hawke (1994) are clearly intended, at least in part, to influence the way in which their governments will be regarded in the future. Peter Walsh's Confessions of a Failed Finance Minister (1995) is both a defence of the economic and social policies Walsh espoused and a bitter attack on those policies and individuals he opposed. The recently published In Command of History (2004) by David Reynolds shows how the prime motivations for Churchill writing his The Second World War were to secure his reputation and to shape our understanding of the conflict and our image of Churchill the prime minister. Another was to make money. Churchill had no hesitation in distorting the truth and censoring the records to achieve his aim. But he achieved his purposes.

\section{Questions of Sources and Methodology}

The term 'triangulation' was used to describe what many regard as basic research - checking and double checking information. As Pat Weller put it, when there were two in the room, if you can, ask both what happened. Political scientists (and others) should stop using jargon. Simple English will suffice. Indeed, the term 'triangulation' is far better known to political scientists as being the term used by Clinton adviser Dick Morris to explain his policy of urging Clinton to distinguish himself from congressional Democrats as well as congressional Republicans (Morris 1999).

Ian Hancock noted the wealth of material available in the National Archives of Australia (NAA) on the Liberal Party that seem to have been mined by few. Lenore Coltheart referred to the value of the World Wide Web, and in particular the National Archives' website devoted to Australian prime ministers and to its 'uncommon lives' pages, in particular those for Jessie Street. ${ }^{3}$ The Archives' collection on Australia's prime ministers including documents, photographs, sound, films and videotape, and the links to many other collections, is an essential reference source for anyone working on the life and times of the prime ministers. 
The NAA website is a virtual nod in the direction of the American presidential libraries, which have spawned so many great (and not so great) biographies. Nicholas Brown spoke of what will be an outstanding contribution to the study and writing of Australian biography, the project to publish the Australian Dictionary of Biography Online in fully searchable form with links to other archival and bibliographical resources.

Neal Blewett wrote about the debate in Cabinet in July 1992 concerning the destruction or retention of the notebooks used by Cabinet Office staff who attend Cabinet meetings and prepare the minutes. The notebooks are now permanently retained, but unlike most Commonwealth records are not available until 50 years have elapsed.

On a personal note, when the Archives Bill 1983 was being drafted, I together with George Nichols - the then First Assistant Secretary, were among the cabinet officers arguing that the notebooks should be brought within the provisions of the proposed legislation and permanently retained. Perhaps not coincidentally, we both had degrees in history. Our view did not prevail. That Bill did not refer to the cabinet notebooks. Their existence continued to be, if not a secret, not publicised. However, early in the 1990s the view strongly argued by several senior officials (in both the Department of the Prime Minister and Cabinet and the NAA, where Nichols was Director-General) that if the notebooks were not brought under the Archives Act there was a real risk that some day there would again be attempts to destroy these valuable records prevailed and their proposed retention went before Cabinet. The Prime Minister and Cabinet (Miscellaneous Provisions) Act 1994 brought the notebooks under the control of the Archives with the 50 year release date. It was a near run thing.

But a word of caution to those slavering at the thought that one day they will be able to access the cabinet notebooks. I doubt that at least some of the entries in the notebooks (assuming they can be read) will tell us more than what is already known through the minutes. In my time in the Cabinet Office (1980s), there were no rules about how and what was to be recorded in the notebooks. Each note taker made such notes as he or she thought would be useful when writing the minutes. ${ }^{4}$

In A Cabinet Diary Neal Blewett tells how he had deliberately refrained from any consultation of the cabinet notebooks in writing his diary. He would have had access to the cabinet submissions and minutes at the time. There is a convention that former ministers may 'refresh their memory' of the cabinet records they saw when in office when writing their memoirs. That access used to be generously granted, although the letter Blewett read to the workshop, written to him by Max Moore-Wilton, at the time Secretary of the Department of the Prime Minister and Cabinet, suggests that access may in more recent years have been less readily available. 
Before leaving the subject of cabinet records, I offer one further personal anecdote. When I was a cabinet officer, Peter Edwards had recently been appointed the Official Historian of Australia's involvement in Southeast Asian conflicts. He had been granted unrestricted access to cabinet and departmental records. One day, while Peter was sitting in the Cabinet Office tapping away at a manual typewriter, staff were cleaning out the large walk-in vault where the records were kept. They found on a back shelf an envelope that had been sealed by Sir John Bunting, Cabinet Secretary from 1959-75. That envelope contained the original correspondence between the Australian and other governments concerning our entry into the Vietnam War. There may have been no other copies of at least some of this correspondence, which was promptly copied and made available to Edwards. The originals were despatched to the Australian Archives.

Since the advent of the Freedom of Information legislation and e-mail, the biographer and historian of the future will find the written records of the public services very sparse in contrast to the records before, say, the 1970s. The ubiquitous detachable yellow post-it notes are a boon to the public servant concerned with a future FOI request, but a curse to the researcher.

\section{Who owns the story, and how far should one delve into the private as distinct from public life?}

Most Australian political biographies tend to concentrate on the office rather than the individual. Paul Strangio's well received Keeper of the Faith: A biography of Jim Cairns (2002) is an exception to this rule, giving as it does a balanced account of Cairns' personal integrity with his failure as a minister. While not a biography in the traditional sense, Judith Brett's, Robert Menzies' Forgotten People, is another instance where the influence of the private life on the public life is critically examined. Pat Weller has made clear that, in his books on Malcolm Fraser and John Button, he was concerned not with writing a biography but with the way political institutions work, the way power is exercised, the interactions between individuals and the institutions in which they work and which they in part shape and which shapes them. When the office door closed, he lost interest in their lives.

Yet as Geoffrey Bolton pointed out, reticence to look into the private life can detract from the value of a political biography. He cited as an example Ross McMullin's generally lively and informative study of Labor Prime Minister Chris Watson (2004) that tersely informs us that Watson's premature retirement from federal politics was due to his wife's complaints about his frequent absences from home in Sydney. 'One would never know that Watson's concern for his wife arose partly because his presence helped her in a battle against alcoholism, nor that after her death he re-married and somewhat belatedly found fulfilment as a parent'. 
There is clearly a problem in writing about a living person. The restrictive defamation laws across Australia are an obvious hurdle. Jenny Hocking was not the first biographer to find that her subject, the lawyer, politician and judge, Lionel Murphy, 'lived a prodigious public life, and yet remained an intensely private man'. There is also the problem such as that faced by Tim Rowse, to whom Nugget Coombs and his family made clear that Coombs' private life was out of bounds. As Rowse notes in the Introduction to Nugget Coombs: A reforming life (2002), 'The resulting book is more impersonal than most readers of biographies would wish'. There is no such reluctance to inquire into a subject's personal life in, for example, David Day's Chifley (2002) where the prime minister's extramarital affairs are examined in detail and the reader is taken literally into Chifley's bedroom. Bob Hawke's biographer (and now wife), Blanche d'Alpuget, made no secret of her subject's drinking problem.

The question is, how far do you need to go to understand the person about whom you are writing? Some in the media prefer the view from the bedroom or the hotel bar. I simply question whether this is always a relevant view. On the other hand, it is at least arguable that a good biography does not make a distinction between the subject's public and private life. While the subject's life should be the focus of intensive study, it should also be the vehicle for a wider observation of human nature and the human condition. 'If it is relevant to a biographer of Churchill that he was a failure at Harrow, it is relevant to a biographer of Atlee that he had a difficult wife and to a biographer of Lloyd George that he kept a mistress' (Pimlott 1990: 222). Bolton noted Laurie Fitzhardinge's reluctance to refer to Billy Hughes' fear of homosexual rape and the influence this must have had on Hughes' attitude to the possession and use of power in a Hobbesian world of potential violence, and to La Nauze being temperamentally unsuited to the sympathetic explanation of Deakin's mystical streak.

Jim Walter argued that a good political biography, particularly one written about someone still living or recently dead, is not written for the political party, the leader and acolyte. While the author needs to be aware of these sensitivities, he or she should be writing for those whose lives were affected by their subject. In Walter's view, that is who you are trying to write for - not necessarily to give them what they want, but to persuade them of why things turned out as they did, why things happened in the way they happened. His anecdote about the reviewer who complained that The Leader 'didn't give my Whitlam back to me' well illustrates the problem an author faces when writing about a prominent figure who has inspired both hate and admiration.

Because the subject of the biography may have been dead for many years does not provide an author with immunity from criticism by members of the family and friends, as David Day found when Menzies \& Churchill at War (1986), John 
Curtin: A Life (2000) and Chifley (2002) were published. The shorter the period of a writing after the death, clearly the greater the angst that will arise when dealing with the family. As Virginia Woolf put it: 'The widow and the friend are hard task masters' (cited in Pimlott 1990: 219).

I recently wrote an entry for the Australian Dictionary of Biography on Harold Bayard Piper, chief judge of the Arbitration Court during the Second World War (vol 16, 6). I would like to expand that entry into a long article or book. For a range of reasons, I have yet to do so. I feel a little uncomfortable at my dilatoriness because Piper's family were very generous to me in making material available and extending hospitality when I visited Melbourne for research. Our views on Piper differ a little. This is a problem faced by those who write about the living or where there is a living family. Few take the robust view John Gorton did when, in essence, he told Ian Hancock that as his biographer he could write whatever he liked about him, and went out of his way to assist Hancock obtain access to those who knew where a skeleton might be buried. It is a great pity more biographical subjects do not adopt the Duke of Wellington's approach of 'publish and be damned!' when the courtesan Harriette Wilson threatened to publish her memoirs and his letters.

There is the difficulty of either liking or disliking your subject. Tracey Arklay referred to coming to like her subject, Arthur Fadden. I respect Piper. When David Marr wrote the biography of Garfield Barwick (1980) he started not liking his subject because of his role in the 1975 Dismissal, but otherwise knew almost nothing about him. However, as he came to know more about Barwick, Marr came to discover much to admire in the man, for example, his sheer skill of the advocate. Rae Wear (2002: xi) did not change her view that Joh Bjelke-Petersen's premiership was an authoritarian and undemocratic regime, but she was compelled to 'acknowledge and try to take account of alternative perceptions and his disarming qualities'. Fin Crisp knew and admired Ben Chifley (1960). As Geoffrey Bolton observed, Crisp presented Chifley 'as a sagacious and practical statesman, almost without fault whose vision Labor [then in Opposition in the federal parliament] needed to recover'.

\section{The problem of gender bias}

Biography has moved on since the writing of Ecclesiasticus: 'Let us now praise famous men and their fathers that begat them!' I am not sure that now there is such a bias, but rather the abysmal representation of women in parliament is the reason for there being so few biographies and autobiographies about Australian women politicians. Those that we have are, for the most part, of little value to the political scientist. (There is no shortage of major biographies of, say, Margaret Thatcher (Young 1989; Campbell 2000; 2003) and Indira Gandhi (Frank 2001). 
In Australia there is Susan Ryan's Catching the Waves (1999). There is Cheryl Kernot's biography (O'Reilly 1998) and then autobiography (2002) (the reason for its low sales in part being because her book tour was cancelled immediately after Laurie Oakes' expose in The Bulletin and on Channel 9 of her relationship with Gareth Evans). There are Dame Enid Lyons' several books of memoirs (c1949; 1965; 1972), and autobiographies by Zara Holt (1968) and Hazel Hawke (1992). There are Kerry Chikarovski's autobiography, Chika (2004), and Franca Arena's Franca: My story (2002). Pauline Hanson is covered in Margo Kingston's Off the Rails: The Pauline Hanson trip (1994) and John Pasquarelli's The Pauline Hanson Story (1998).

Other books include Junie Morosi's Sex, Prejudice and Politics (1975) and Anne Summers' account of her early life (2000); regrettably it appears that we are not going to see a volume covering her period as a senior adviser to the Prime Minister. After these, I am struggling to think of other books by and about women politicians, public servants and those who worked in and around a parliament house. One other book that should be noted, surprisingly not mentioned during the workshop, is Diane Langmore's Prime Ministers' Wives: The public and private lives of ten Australian women (1992). A woman whose account of her time in the federal Parliament House we sadly miss is that of Ainslie Gotto, although Ian Hancock has acknowledged his debt to her for the assistance she provided when writing John Gorton: He did it his way (2002).

\section{Gaps in administrative memoirs}

Regrettably, there is a dearth of administrators' memoirs, accounts by federal and state public officials of their working life. What we have is sparse and of uneven quality. Nor do we have books of the quality of Peter Hennessy's Whitehall (1989) and Cabinet (1986) that show in detail the inner workings of our public services. Pat Weller's forthcoming book on the federal cabinet may fill one gap, but where is the equivalent of Whitehall? Nor are there many good biographies of public servants.

One problem is the various secrecy provisions in public servants' employment conditions, and legislation that explicitly forbids the disclosure of information that has come to the public servant's notice in the course of their duties. They do not have the same opportunity, however limited, of Commonwealth ministers being able to 'refresh' their memory. There is also the strong tradition, although possibly now a bit frayed around the edges (Wilkie 2004) of public servants having a strong ethic of confidentiality. The various codes of conduct formally reinforce this traditional reticence. It is also probable that by the time most public servants have retired they do not feel inclined to spend their retirement researching their administrative past. Few serving (and former) public servants are prepared to speak on the record, although Pat Weller has left us a treasure trove in his Australia's Mandarins: The frank and the fearless? (2001) which 
draws upon interviews with over 100 past and present Commonwealth departmental heads. As Weller noted, 'If the public face of government can be found among the elected representatives, the public servants provide the sinews and muscle that make the body politic work' (2001: 3). No biography of a minister can ignore the influence he or she had upon their department - and that of the department on the minister.

There are, however, a few memoirs by senior federal (and state) public servants, although a number of agency histories now exist. There is a strong slant towards the memoirs of Foreign Affairs and Defence officers. There are a number of books and monographs about and by heads of the Department of Foreign Affairs, in particular.

Regrettably, we have very few accounts by career public servants which give attention to the administrative routine, rather than to career highlights. Richard Woolcott, the former Secretary of the Department and Foreign Affairs and Trade, makes clear in the title of his memoirs The Hot Seat: Reflections on diplomacy from Stalin's death to the Bali bombings (2003) where his primary interest lay. The occasional paper derived from the transcript of oral history interviews with one of his predecessors, Sir Keith Waller (1990), similarly favours diplomacy over administration. Sir John Bunting's affectionate memoir of a man he clearly admired, R. G. Menzies: A portrait (1988), tells a little about the relationship between one permanent head and his minister, but the emphasis is very much on Menzies rather than departmental administration. What we are told about the relationship of senior officials with the prime minister is very much the view of a mandarin and his regard for what he terms 'due process' (Bunting 1988; see also Hancock 2002). However, as Weller points out in his survey of research on the Commonwealth executive, Bunting's book is also 'an account, and a defence, of Cabinet government in the 1950s and 1960s' (2005: 36). John Menadue's account of his term as Secretary of the Department of the Prime Minister and Cabinet in Things You Learn Along the Way (1999) is a useful record of the development of that department's 'activist role' which started under Whitlam and continued under Fraser, and of the 'Loans Affair' and The Dismissal. He briefly covers his tenure as Ambassador to Japan and as Secretary to the Department of Immigration and Ethnic Affairs, and, later, Trade.

One exception, albeit slight, to the paucity of administrative memoirs by senior Commonwealth public servants is They Also Serve (1974), the memoirs of Sir William Dunk, chairman of the Commonwealth Public Service Board, 1947-1960. (Dunk preferred the term 'Notes' of his 'worm's eye view' through a full generation of official experience.) These notes include, for example, the detailed memorandum the Board put to Cabinet in June 1947 outlining the action the Public Service Board has taken, and the policies it proposes to follow, in carrying out its duties of staffing, organization and efficiency in the Public Service' at a 
time the service was being concentrated in Canberra. Dunk gives us an insight into his character when he tells us that Cabinet's acceptance of the Board's submission 'was a comfort (it is a useful thing to have a powerful piece of paper to wave under the nose of objectors)'. We also gain a slight understanding of his relationship with Prime Minister Menzies, who when asked on his appointment as prime minister in 1949, to endorse the memorandum 'gave a lordly wave of the hand and said "Carry on Sergeant-Major".

We also have Nugget Coombs' 'guarded and occasionally misleading account of his public life', Trial Balance (1981). Another account by a senior public servant, albeit in this instance one who did not look so favourably on his experience of the Australian public service, is that of Dr. V. G. Venturini. His vitriolic Malpractice: The administration of the Murphy Trade Practices Act (1980) covers his term as a commissioner on the Trade Practices Commission from early 1975 to 30 June 1977. Venturini does not share the affection for the public service which is so obvious in the works of Bunting and Dunk. To Venturini, the 'true bureaucracy - the top public service - still services: itself first and foremost, second, the rich; and moreover, it does that at the expense of the rest of the Australian community'. No Grey Profession, the memoirs of a director-general of the National Library, Harrison Bryan, are a far more sympathetic account of the institutions in which he worked, as are those of Frank Green, Clerk of the House of Representatives 1937-1955 (Bryan 1994; Green 1969).

While not a biography in the traditional sense, mention should be made of David Horner's valuable Defence Supremo: Sir Frederick Shedden and the making of Australian defence policy (2000). There is the biography of Robert Broinowski, secretary to three post-federation Ministers of Defence who retired in 1942 as Clerk of the Senate, written by his grandson, a former senior officer of the Department of Foreign Affairs and Trade (2001). But biographies of public servants are all too few. Peter Edwards' biography of Sir Arthur Tange adds to a very small library of major biographies of public servants, federal or state. While we have his memoirs, Prosper the Commonwealth, a biography of the first Secretary of the Commonwealth Attorney-General's Department, Sir Robert Garran, is long overdue. There are also the several books by and about Charles Perkins, the first departmental secretary of Aboriginal descent (Perkins 1975; Read 1990).

\section{Conclusion}

During the workshop reference was made to dozens of autobiographies, biographies and administrative memoirs that may help us to understand better how government and the public service work, why they work (if they do) in the way that they do, and how individuals, particularly senior politicians, both shape government and are, in turn, influenced by their political and administrative colleagues and processes. The quality of all these works is uneven; 
it is a wonder some found a publisher. Others will be read, and mined, for years to come. The spread of publications across the federal and state arenas is also uneven, as it is across the various public sector agencies.

The term 'political biography' is of doubtful value, suggesting as it does some compartmentalised genre separate from the that of history or biography. Rather, what we are seeking are biographical accounts that contribute to our understanding of the Australian political and administrative systems. We are fortunate that we have many such works available to us. But many more are needed; from politicians, their staff, party officials, public servants and academics, journalists and others.

\section{ENDNOTES}

1 It is bad enough that some historians still claim that biographers are mere showmen at best, quacks at worst. As Professor Patrick O'Brien, a former Director of the University of London's Institute of Historical Research put it, political biographies are informed by mere 'concerns to instruct and entertain their readers', and 'tell historians all too little about the core aspirations of their discipline, which are to acquire a proper understanding of evolving political institutions and processes' (!), cited in Pimlott 1990: 31).

2 For Marilyn Dodkin's 2003 'Bob Carr: the Reluctant Leader', the author was granted access to Carr's private diaries.

3 See http://uncommonlives.naa.gov.au/ also www.jessiestreetwomenslibrary.com).

4 For an account of the purpose of the notes and their authority, see the Full Federal Court's decision in Commonwealth v Northern Land Council (1991) 103 ALR 267, esp. at 276-279 and the High Court's decision in Commonwealth v Northern Land Council (1993) 176 CLR 604. 